\title{
PERLINDUNGAN HUKUM KEPADA KONSUMEN TERHADAP PENGGUNAAN KLAUSULA BAKU YANG TERCATUM PADA TOKO ONLINE
}

Oleh:

\author{
Putu Dina Marta Ratna Sari* \\ I Made Dedy Priyanto**
}

Fakultas Hukum Universitas Udayana

Program Kekhususan Hukum Bisnis

\begin{abstract}
ABSTRAK
Klausula baku tercantum dalam toko online yang berbasis pada media sosial instagram mencantumkan klausula baku tidak menerima pengembalian barang atau refund yang secara tidak langsung telah membatasi hak konsumen dalam mendapatkan perlindungan hukum jika produk yang dipesannya berbeda atau tidak sesuai dengan produk yang diperjanjikan. Penulisan ini mengemukakan dua rumusan masalah, yakni: bagaimana pengaturan klausula baku, bagaimana perlindungan hukum terhadap konsumen dalam pemberlakuan klausula baku pada transaksi perniagaan elektronik. Penulisan ini menggunakan metode penulisan hukum normatif dengan menggunakan pendekatan perundangan dan pendekatan konsep hukum. Hasil dari penelitian ini adalah penggunaan klausuka baku dalam transaksi elektronik dan belanja online dibatasi penggunaannya, pembatasan yang dimaksud dengan tidak mencantumkan klausula yang telah diatur dalam Undangundang. Perlindungan hukum kepada konsumen yang dirugikan haknya dapat melaporkan dan menuntut penjual ke Badan Penyelesaian Sengketa Konsumen, melalui Undang-Undang Perlindungan Konsumen, hak hak konsumen dapat terjamin dan terlindungi.
\end{abstract}

Kata Kunci: Klausula baku, Perlindungan Konsumen, Toko online

\section{ABSTRACT}

The standard clauses listed in online stores based on Instagram social media include the standard clause does not accept return of goods or refund which indirectly limits the consumer's rights in obtaining legal protection if the goods ordered are not in accordance with the agreement after the goods are received by the consumer. This writing presents two problem formulations, namely: how to regulate standard clauses, how is

* Putu Dina Marta Ratna Sari adalah Mahasiswa Fakultas Hukum Universitas Udayana, korespondensi dengan penulis melalui emai: dinamarta81@gmail.com Udayana 
legal protection for consumers in the implementation of standard clauses in electronic commerce transactions. This writing uses the method of writing normative law using a legal approach and a legal concept analysis approach. The result of this research is the prohibition on the inclusion of standard clauses has been regulated in the Consumer Protection Act. Consumer protection is actually synonymous with the protection given by law concerning consumer rights. Consumer protection means questioning guarantees or certainty about fulfilling consumer rights.

\section{Keywords: Standard clause, Consumer Protection, online shop}

\section{Pendahuluan}

\section{$1.1 \quad$ Latar belakang}

Digitalisme seluruh aspek kehidupan yang berpengaruh terhadap perkembangan perdagangan serta perkembangan ilmu hukum. Digitalisasi dan globalisasi memudahkan aktifitas dalam kegiatan perekonomian, baik dalam bentuk perdagangan secara konvensional maupun secara online. Dengan menggunakan akses internet seluruh kegiatan jual beli dapat lebih mudah dilakukan dan dirasa lebih praktis dalam perkembangan era digital dan pergerakan arus globalisasi. Pesatnya perkembangan internet berdampak pada terbentuknya suatu sistem perdagangan di dunia maya atau disebut sebagai E-commerce (perniagaan elektronik) sebagai suatu basis segala macam bentuk transaksi jual beli. Dengan melakukan transaksi perniagaan elektronik dapat memudahkan melakukan transaksi jual beli.

Transaksi dalam perniagaan elektronik rentan terhadap kejahatan, seperti penipuan yang diatur dalam Undang-Undang Nomor 11 Tahun 2008 Tentang Informasi dan Transaksi Elektronik. Dalam perniagaan elektronik juga dapat merugikan konsumen seperti ketidak sesuaian barang yang dipesan dengan yang tertera pada media promosi, kesalahan ukuran, dan berbagai macam bentuk kerugian yang diderita oleh konsumen. Terdapat suatu perjanjian jual beli dalam melakukan transaksi pada perniagaan elektronik, sehingga menimbulkan suatu perikatan yang bersumber 
dari perjanjian. Perniagaan elektronik semestinya mengikuti peraturan yang ada, maka semestinya memenuhi unsur-unsur jual beli dalam KHUPerdata. Dalam menjamin kebutuhan masyarakat terhadap percepatan akses jual beli dan digitalisasi perdagangan serta mendukung adanya transaksi jual beli secara online, pemerintah menerbitkan Undang-Undang Nomor 11 Tahun 2008 Tentang Informasi dan Transaksi Elektronik lengkap dengan peraturan pemerintah mengenai penyelenggaraan sistem dan transaksi elektronik. Peraturan ini diundangkan sebagai jaminan terhadap perlindungan hukum dari pemerintah kepada konsumen sehingga tidak terjadi ketimpangan dan tercipta rasa keadilan antara hak dan kewajiban baik dari produsen atau pelaku usaha dan khususnya bagi konsumen.

Pada sebuah sistem perniagaan elektronik, terdapat empat komponen yang diperlukan dalam transaksi perniagaan elektronik, yakni pada toko, penjual dan pembeli, jasa pengriman. Transaksi perniagaan elektronik terdapat pihak- pihak yang menjadi subyek hukum dan memiliki hubungan hukum antara pelaku usaha atau penjual (toko online) dengan konsumen, serta ditambah dengan pihak penyedia jasa aplikasi belanja online. ${ }^{1}$

Beberapa toko online mencantumkan adanya klausula baku pada kuitansi yang dibuat oleh toko online itu sendiri, terutama toko online yang memanfaatkan media sosial sebagai media promosi dan sebagai lapak jualannya sehingga tidak memerlukan jasa penyedia aplikasi belanja online. Klausula baku yang biasanya tercantum adalah tidak menerima pengembalian barang atau refund yang secara tidak langsung telah membatasi hak konsumen dalam mendapatkan perlindungan hukum jika produk barang yang telah

1 Firman Tumantara, 2016, Hukum Perlindungan Konsumen, Setara Press, Malang, h.5. 
disepakati pemesanannya tidak sesuai dengan yang diharapkan saat produk barang tersebut diterima oleh konsumen melalui jasa pengiriman barang. Isi klausulan baku merugikan pihak yang menerima klausula baku karena dibuat secara sepihak. ${ }^{2} \mathrm{Hal}$ tersebut melanggar sebagian dari hak dari konsumen sebagaimana diatur dalam Pasal 4 huruf b Undang-Undang Nomor 8 Tahun 1999 Tentang Perlindungan Konsumen yang artinya hak untuk memilih barang dan/jasa serta mendapatkan barang dan/jasa tersebut sesuai dengan nilai tukar dan kondisi serta jaminan yang dijanjikan.

\subsection{Rumusan masalah}

Berdasakan uraian pada sub bab latar belakang diatas, penulis merumuskan dua rumusan masalah dalam penulisan jurnal hukum ini sebagai berikut:

1. Bagaimana pengaturan klausula baku yang berkaitan dengan aspek perlindungan konsumen?

2. Bagaimana perlindungan terhadap konsumen yang menerima klausula baku dari toko online?

\subsection{Tujuan Penelitian}

Penelitian ini bertujuan untuk, memahami, mengetahui dan memberikan kontribusi keilmuan terkait teori-teori ilmu hukum, serta perkembangan ilmu hukum bisnis atau keperdataan. Tujuan khusus dari penulisan ini adalah mengetahui dasar hukum dari klausula baku dan pengaturannya dalam sistem perundangan yang berlaku serta konsep klausula baku dalam transaksi e-commerce

\section{Pembahasan dan Isi Makalah}

\subsection{M etode Penelitian}

2 Zulham, 2013, Hukum Perliindungan Konsumen, Kencana, Jakarta, h.69. 
Metode adalah salah satu instrumen yang menentukan jalannya penyusunan sebuah karya tulis. ${ }^{3}$ Dalam kaitannya dengan itu, maka metode dalam penyusunan journal ini adalah metode penelitian hukum normatif (doctrinal research) yang pada dasarnya menjadikan produk hukum sebagai kajian utama dan data primer dalam mengidentifikasi sebuah persoalan. ${ }^{4}$ Disamping itu, Pendekatan dalam penulisan ini menggunakan pendekatan perundangan dan pendekatan konsep hukum. ${ }^{5}$

\subsection{Pengaturan Klausula Baku Yang Berkaitan Dengan Aspek Perlindungan Konsumen}

Klausula baku pada umumnya dilakukan atau diterapkan oleh pelaku usaha kepada konsumen. Isi dari klausula baku yang dibentuk, dibuat dan diberlakukan secara sepihak oleh pelaku usaha dapat menimbulkan kerugian bagi konsumen. Penolakan dari konsumen terhadap pemberlakuan klausula baku yang dilakukan oleh pelaku usaha, maka konsumen tidak akan dilayani dalam hal transaksi jual beli secara online sehingga konsumen tidak mendapatkan produk yang diinginkan dari pelaku usaha yang memberlakukan klausula baku tersebut. Secara tidak langsung dan atau dengan keadaan terpaksa para konsumen memilih untuk menyetujui isi dari klausula baku yang diterapkan pelaku usaha. ${ }^{6}$

Istilah klausula baku atau perjanian baku (standard contract) dapat didefinisikan sebagai sebuah acuan atau ketetapan. Klausula baku yang didefinisikan oleh Mariam Darus adalah bentuk lain dari sebuah perjanjian yang isi dari pada perjanjian tersebut dibakukan

\footnotetext{
3 Suprapto, 2013, Penelitian Kuantitatif dan Kualitatif, CAPS, Bogor, h.63.

4 A. Muktie Fajar dan Yulianto Ahmad, 2010, Dualismen Penelitian Hukum Normatif dan Empiris, Pustaka Pelajar, Yogyakarta, h.53.

5 H. Bahdin Nur Tanjung dan H. Ardinal, 2009, Pedoman Penulisan Karya Ilmiah, Kencana, Medan, h.62.

6 Abdulkadir Muhammad, 2014, Perjanjian Baku dalam Praktik Perusahaan Perdagangan, Citra Aditya Bakti, Bandung, h.10
} 
atau dituangkan ke dalam bentuk formulir. ${ }^{7}$ Selain Marian Darus, klausula baku juga didefinisikan oleh Hondus. Menurut Hondus, klausula baku merupakan sebuah konsep atau janji yang telah disusun secara tertulis tampa memperhatikan isi dari perjanjian atau klausul tersebut. ${ }^{8}$

Undang-Undang Perlindungan Konsumen mengatur mengenai klausula baku pada Pasal 1 angka (10). Pengertian klausula baku berdasarkan ketentuan pasal tersebut merupakan sebuah peraturan atau ketetapan serta persyaratan yang dipersiapkan sebelumnya dan telah ditetapkan secara sepihak oleh penjual atau pelaku usaha yang dalam hal ini adalah toko online, dan dituangkan kedalam bentuk dokumen ataupun perjanjian secara mengikat dan wajib dipenuhi. Pada transaksi jual beli online sangat jarang diberlakukan sebuah dokumen atau perjanjian tertulis, para penjual atau pelaku usaha yang berbasis secara online hanya menentukan klausula baku melalui pernyataan pada biodata yang tertulis pada platform toko online tersebut.

Konsumen memiliki hak untuk mendapatkan suatu kompensasi atau ganti rugi dari pihak penjual atau pelaku usaha, serta konsumen memiliki hak untuk mendapatkan penggantian barang atau produk yang telah dipesan namun tidak sesuai dengan pesanan yang telah disepakati. Hak konsumen tersebut dijamin dalam Pasal 4 Undang-Undang Perlindungan Konsumen. Perlindungan yang diberikan kepada konsumen telah ditegaskan dalam Pasal 7 Undang-Undang Perlindungan Konsumen. Pada ketentuan tersebut konsumen dilindungi karena pelaku usaha atau penjual memiliki kewajiban untuk memberikan ganti rugi atau kmpensasi serta penggantian produk.

7 Mariam Darus Badrulzaman, 2011, Aneka Hukum Bisnis, Alumnii, Bandung, h.47.

8 Ibid. 
Pelaku usaha dilarang menyatakan atau memberikan klausul "berhak menolak penyerahan kembali barang yang dibeli konsumen" atau dalam hal kegiatan jual beli online lazim dinyatakan sebagai "no refund". Pelaku usaha juga dilarang menyatakan berhak menolak pengembalian uang atau dana yang telah dibayarkan terhadap produk yang telah dibeli oleh konsumen. Pada transaksi perniagaan elektronik, klausula baku dilarang apabila penjual menyatakan "no refund" atau menolak pengembalian uang yang telah dibayarkan oleh konsumen. Klausula baku ini sering dicantumkan oleh pedagang yang menjajakan produknya atau mempromosikan produknya pada media sosial instagram. Para pelaku usaha biasanya mencantumkan "no refund" dengan terjemahan bebas, tidak ada pengembalian atau juga berarti tidak dapat ditukar dengan barang yang sama.

Segala bentuk klausula baku yang diterapkan oleh pelaku usaha atau dalam hal ini toko online dinyatakan batal demi hukum berdasarkan Pasal 18 angka (2) UUPK. Batal demi hukum diartikan sebagai persyaratan atau klausul yang terdapat dalam klausula baku yang dicantumkan atau diberlakukan oleh pelaku usaha dianggap tidak pernah diberlakukan. Sanksi bagi pelaku usaha yang tetap memaksakan kehendaknya memberlakukan klausula baku seperti yang telah diuraikan diatas, diancaman dengan pidana penjara maksimal lima tahun atau denda maksimum dua miliar rupiah.

\subsection{Perlindungan Terhadap Konsumen Yang Menerima Klausula Baku Dalam Transaksi Online}

Perlindungan terhadap konsumen merupakan salah satu instrumen perlindungan hukum kepada konsumen dalam hal terjadi kerugian atau pelanggaran hak-hak konsumen yang 
dilakukan oleh pelaku usaha. Undang-Undang perlindungan Konsumen menjamin adanya kepastian hukum dalam hal memberikan perlindungan kepada konsumen, khususnya dalam hal transaksi jual beli online. Perlindungan konsumen dalam hal transaksi jual beli secara online terdiri dari perlindungan terhadap jaminan kesesuaian barang yang diperjanjikan atau yang telah disepakati dengan barang yang diterima merupakan barang yang sama seperti pada kesepakatan antara penjual dengan pembeli. Perlindungan juga dapat berupa perlindungan terhadap pemberlakuan syarat yang kurang adil kepada konsumen, salah satunya penerapan klausula baku. ${ }^{9}$

Perlindungan hukum diperlukan dalam hal transaksi perniagaan secara online, karena layanan atau platform berbelanja online sering mengabaikan hak-hak konsumen, selain itu toko online yang berdiri sendiri atau tidak memanfaatkan layanan jasa jual beli online juga sangat mengabaikan hak-hak konsumen dan sangat riskan terhadap penipuan dengan modus operandi jual beli online. ${ }^{10}$ Hak-hak dasar konsumen yang perlu diperhatikan oleh platform jual beli online seerta toko online yang berdiri sendiri, antara lain: hak untuk mendapatkan informasi, hak untuk memilih hak mendapatkan keamanan, hak untuk didengar. ${ }^{11}$

Perlindungan kepada konsumen tidak serta merta berupa perlindungan fisik konsumen, tetapi meliputi hak-hak yang dimiliki konsumen dengan keabstrakan sifat dari pada hak-haknya yang melekat tersebut. Perlindungan konsumen merupakan sebuah perlindungan hukum terhadap hak-hak dari konsumen, hal ini

9 Zulham, 2014, Hukum Perliindungan Konsumen, Prenada Media Grup, h.22.

10 Abdull Hakim Barkatullah, 2011, HakHak Konsumen, Nusa Mediia, Bandung, h.24.

11 Celiina Trii, 2014, Hukum Perlindungan Konsumen, Sinar Grafika, Jakarta, h.33. 
tercermin dalam peraturan perundangan yang mengatur mengenai perlindungan konsumen serta transaksi secara elektronik. ${ }^{12}$ Perlindungan konsumen merupakan jaminan terhadap terpenuhinya hak-hak konsumen dan kewajiban pelaku usaha untuk menjaga dan tidak menerobos atau melanggar hak-hak yang dimiliki konsumen. Terjaminnya suatu perlindugan hukum kepada konsumen tercermin dari rendahnya tingkat pelanggaran terhadap hak-hak yang dimiliki konsumen sehingga tercapainya suatu kepastian hukum bagi konsumen itu sendiri dan pelaku usaha. ${ }^{13}$

Undang-Undang Perlindungan Konsumen menegakan dan memberi kepastian hukum terhadap konsumen dalam hal menjamin dan terpenuhinya hak-hak yang dimiliki konsumen, serta memberikan batasan dan tanggung jawab dari pelaku usaha untuk bersikap jujur dalam kegiatan transaksi jual beli secara online, sehingga tercipta suatu keadilan antara konsumen dengan pelaku usaha. Diaturnya klausula baku dalam UUPK tidak bermaksud untuk mendiskreditkan pelaku usaha dan mengabaikan kepentingan pelaku usaha, tetapi memiliki tujuan untuk menciptakan keseimbangan dan keadilan dalam hal perlindungan hukum terhadap kegiatan jual beli online. ${ }^{14}$ Toko online tidak dapat dituntut atau dipersalahkan atas pemberlakuan klausula baku yang menolak refund kepada konsumen.

Konsumen yang secara sadar dan sepakat dengan isi dari klausula baku yang dicantumkan pelaku usaha atau toko online pada kolom biodata akun media sosial toko online ataupun pada penyedia jasa perniagaan online, maka para pihak yang sepakat dengan ketentuan yang diberlakukan telah dapat dikatakan sebagai

12 Shiidarta 2014, Hukum Perliindungan Konsumen Indonesiia, Grasiindo, Jakarta, h.29.

13 Ibid.

14 Miru Ahamdi dan Sutarman Yodo, 2012, Hukum Perliindungan Knsumen, Raja Grafindo Persada, Jakarta, h.119. 
suatu bentuk perikatan dan perjanjian. Langkah-langkah yang perlu dilakukan dalam hal penggunaan klausula baku dalam transaksi perniagaan secara elektronik adalah mengawasi dan membatasi penggunaan klausula baku yang merugikan konsumen atau bertentangan denngan ketentuan peraturan perundangan. Pembatasan serta larangan pencantuman klausula baku dalam kegiatan perdagangan terutama dalam hal transaksi perniagaan secara elektronik bertujuan untuk mencegak terjadinya kekuasaan berlebih oleh pelaku usaha pada suatu keadaan tertentu yang dimana dapat merugikan dan melanggar hak-hak dari konsumen.

Konsumen dapat menggugat pelaku usaha ke pengadilan tempat konsumen berdomisili. Dalam hal penyelesaian perselisihan yang timbul dari adanya kegiatan jual beli yang merugikan konsumen, hak untuk menggugat ini dapat dilakukan apabila pelaku usaha tidak memberikan respon atau tanggapan dalam hal tuntutan ganti rugi atau tuntutan pengembalian barang dan atau uang yang telah dibayarkan kepada konsumen berdasarkan ketentuan Pasal 23 UUPK. Undang undang menjamin hak-hak dari konsumen terhadap pelaku usaha yang tidak memberikan tanggapan. Konsumen juga diberi kebebasan dalam hal menentukan penyelesaian sengketa berdasarkan Pasal 45 ayat (2) UUPK, yang dapat dilakukan secara litigasi ataupun non litigasi. 15

\section{Penutup}

\subsection{Kesimpulan}

1 Klausula Baku atau Perjanjian Standar diatur dalam Pasal 1 amgka (10), Pasal 4 huruf b, Pasal 18 angka (1), (2). Toko online yang dengan sengaja tanpa memperhatikan ketentuan mengenai klausula baku seperti yang diatur dalam

15 Nila Juniiati, 2014, Kewajiban Pelaku Usaha Mencantumkan Penggunaan Bahasa Indonesia Pada Produk Elektronik Rumah Tangga di Kota Pontianak, Skripsi Fakultas Hukum Univ. Tajungpura, Pontianak, h.34. 
Undang_undang Perlindungan Konsumen diancam dengan sangsi penjara dan sanksi denda. Apabila konsumen menerima pemberlakuan klausula baku yang tercantum pada kolom biodata akun media sosial instagram toko online ataupun pada penyedia jasa perniagaan online, maka konsumen tersebut secara sadar dan sukarela setuju pada isi perjanjian tersebut.

2 Perlindungan kepada konsumen tidak serta merta berupa perlindungan fisik konsumen, tetapi meliputi hak-hak yang dimiliki konsumen dengan keabstrakan sifat dari pada hakhaknya yang melekat pada konsumen. Undang-Undang perlindungan Konsumen menjamin adanya kepastian hukum dalam hal memberikan perlindungan kepada konsumen, khususnya dalam hal transaksi jual beli online. Dalam hal melakukan perlindungan konsumen, undang-undang memebrikan hak kepada konsumen untuk melakukan penuntutan pada lembaga peradilan, konsumen juga berhak melakukan penyelesaian perkara secara non litigasi.

\subsection{Saran}

Disarankan kepada pelaku usaha, pemilik toko online, serta penyedia jasa toko online untuk lebih mengutamakan dan mengedepankan hak-hak yang diperoleh konsumen. Pelaku usaha juga diharapkan tidak menggunakan klausula baku berlebih yang dapat merugikan atau menghilangkan hak-hak yang dimiliki konsumen. 


\section{DAFTAR PUSTAKA}

\section{Buku:}

Ahamdi, Miru dan Sutarman Yodo, 2012, Hukum Perliindungan Knsumen, Raja Grafindo Persada, Jakarta.

Badrulzaman, Mariam Darus, 2011, Aneka Hukum Bisnis, Alumnii, Bandung.

Barkatullah, Abdull Hakim, 2011, HakHak Konsumen, Nusa Mediia, Bandung.

Fajar, A. Muktie dan Yulianto Ahmad, 2010, Dualismen Penelitian Hukum Normatif dan Empiris, Pustaka Pelajar, Yogyakarta.

Trii, Celiina, 2014, Hukum Perlindungan Konsumen, Sinar Grafika, Jakarta.

Tumantara, Firman, 2016, Hukum Perlindungan Konsumen, Setara Press, Malang.

Muhammad, Abdulkadir, 2014, Perjanj̈an Baku dalam Praktik Perusahaan Perdagangan, Citra Aditya Bakti, Bandung.

Nur Tanjung, H. Bahdin dan H. Ardinal, 2009, Pedoman Penulisan Karya Ilmiah, Kencana, Medan.

Philips, Jerry J. 2013, Product Liability, Wet Publishing Company, St. Paul.

Shiidarta, 2014, Hukum Perliindungan Konsumen Indonesiia, Grasiindo, Jakarta.

Suprapto, 2013, Penelitian Kuantitatif dan Kualitatif, CAPS, Bogor.

Zulham, 2013, Hukum Perliindungan Konsumen, Kencana, Jakarta.

\section{Jurnal:}

I Gusti Ayu Ratih Pradnyani, 2016, "Perjanjian Baku Dalam Perlindungan Konsumen", Jurnal Ilmu Hukum, Fakultas Hukum Universitas Udayana, http:/ / ojs.unud.ac.id, di akses, tanggal 28 November 2018. 
Putu Prasintia Dewi, 2015, Asas Naturalia Dalam Perjanjian Baku, Jurnal Imu Hukum, Fakultas Hukum Universitas Udayana, http://ojs.unud.ac.id, di akses, tanggal 28 November 2018.

\section{Peraturan Perundang-Undangan}

Kitab Undang-Undang Hukum Perdata, Burgelijk Wetboek, 2008, diterjemahkan oleh Subekti, R. dan Tjitrosudibio, Pradnya Paramita, Jakarta.

Indonesia, Undang-Undang Nomor 8 Tahun 1999 tentang Perlindungan Konsumen, (Lembaran Negara Republik Indonesia Nomor 22 Tahun 1999, Tambahan Lembaran Negara Republik Indonesia Nomor 3821).

Indonesia, Undang-Undang Nomor 11 Tahun 2008 tentang Informasi dan Transaksi Elektronik (Lembaran Negara Republik Indonesia Nomor 58 Tahun 2008. Tambahan Lembaran Negara Republik Indonesia Nomor 4843). 